\title{
PEMANFAATAN ASAP CAIR DARI PELEPAH KELAPA SAWIT UNTUK MENINGKATKAN KUALITAS BAHAN OLAH KARET PETANI KARET
}

\author{
Seri Maulina, Erni Misran, Maya Sarah \\ Departemen Teknik Kimia, Universitas Sumatera Utara, Medan 20155, Indonesia \\ E-mail: maulina_harahap@yahoo.com,erni_misran@yahoo.com, mayasharid@yahoo.com
}

\begin{abstract}
An effort in improving field latex quality has been conducted through community service activity for rubber farmers at Dusun Alur Hitam, Sekoci Village, Langkat Regency. The farmers generally use unrecommended coagulant such as fertilizer, extract of mengkudu or fern sap for coagulating their latex that can reduce the quality of rubber. The low quality of field latex, thus in turn reduce its selling price and income of farmers. Liquid smoke produced by pyrolysis of palm frond waste was proposed to be used as latex coagulant. Team of community service has designed and manufactured a pyrolysis reactor for this activity. The pyrolysis process produced brown liquid smoke with $\mathrm{pH}$ of 3 and a strong smoke smell. The produced liquid smoke can coagulate latex perfectly with the time needed were 2',25"; 3',21" and 4',29" at the ratio of liquid smoke to latex were 1:10, 1:15 and 1:20 respectively with the use of liquid smoke of $2 \mathrm{~mL}$. The dry rubber content of latex reached $73.48 \%$. Thus, the utilization of smoke liquid can improve the dry rubber content as high $20.48 \%$ since the rubber buyer agents only set the dry rubber content of 53\%. The elongation at break (EB) of latex was in the range of $165.55 \%-286.93 \%$. it is necessary to increase the knowledge and skill of rubber farmers. In the future, the establishment of farmer group or cooperative at Dusun Alur Hitam should be encouraged so as to facilitate the farmers in selling their product.
\end{abstract}

Keywords: latex coagulant, liquid smoke, palm frond waste

\section{Pendahuluan}

Sumatera Utara merupakan salah satu penghasil karet utama di Indonesia. Hal ini menunjang produksi nasional yang menempatkan Indonesia sebagai negara terbesar kedua penghasil karet alam di dunia setelah Thailand dengan produksi sekitar 3,1 juta ton per tahun. Indonesia merupakan negara yang memiliki areal perkebunan karet terluas di dunia yaitu seluas lebih kurang 3,5 juta hektar pada tahun 2013. Dari total produksi tersebut, sekitar $78,41 \%$ berasal dari hasil perkebunan rakyat, sedangkan $10,36 \%$ berasal dari perkebunan milik pemerintah, dan sisanya berasal dari perkebunan swasta (GAPKINDO, 2014).

Sayangnya pengetahuan para petani tentang sifat-sifat karet serta tatacara pengolahan pasca panen masihlah minim. Hal ini mengakibatkan rendahnya produktivitas nasional serta kualitas karet sehingga menurunkan harga jual produk di tingkat petani. Padahal karet alam merupakan salah satu komoditi unggulan yang menjadi primadona ekspor Indonesia. Untuk itu dibutuhkan penangangan yang serius dan melibatkan berbagai pihak termasuk akademisi.

\section{Analisis Situasi}

Proses pengolahan lateks alam membutuhkan bahan kimia dalam jumlah yang banyak, mengkonsumsi air dengan volume yang besar, serta penggunaan energi yang tinggi. Jumlah pemakaian air dan listrik pada sebuah industri pembuatan crumb rubber (karet alam remahan) sangat ditentukan oleh mutu bahan baku yang digunakan (Maulina, 2015). Jumlah kebutuhan air dan listrik akan meningkat pada proses lanjut jika bahan baku gumpalan karet yang digunakan memiliki tingkat kemurnian serta nilai plastisitas (Plasticity Rubber Index, PRI) yang rendah.

Proses penggumpalan karet di kebun dilakukan dengan penambahan bahan kimia berupa tawas, pupuk, atau asam formiat (asam semut) ke dalam mangkok deres yang produknya dikenal sebagai cup lump. Penggunaan asam sangat berperan dalam menghindari terjadinya degradasi protein pada saat proses penggumpalan karet dan dapat mencegah timbulnya bau yang tidak 
Seri Maulina. et al. Pemanfaatan Asap Cair dari Pelepah Kelapa Sawit Untuk Meningkatkan...

sedap pada karet. Disamping untuk mendapatkan kualitas yang baik bahan kimia dapat pula memberikan dampak negatif terhadap lingkungan sekitar serta memberi risiko terhadap para pekerja terutama pada pernapasan.

Hal umum lain yang sering ditemui dalam bahan olah karet (bokar) hasil perkebunan rakyat adalah berupa adanya bahan-bahan pengotor yang sengaja dimasukkan. Bahan-bahan pengotor itu biasanya berupa tanah liat dan atau serpihan kulit pohon karet yang seharusnya dibuang sewaktu proses menderes lateks. Selain itu, petani karet juga kerap mencelupkan atau merendam bokar mereka ke dalam air dengan tujuan menaikkan bobotnya. Padahal upaya ini dapat menurunkan mutu bokar yang dihasilkan serta menurunkan kualitas air di kawasan sekitar mereka. Sesungguhnya tindakan memasukkan bahan pengotor ke dalam bokar memberikan dampak yang lebih luas kepada industri pengolahan lateks. Diperlukan energi listrik yang tinggi sewaktu melakukan pencacahan bahan baku, serta volume air yang besar yang diperlukan untuk proses pencucian. Kotoran yang dimasukkan dengan tujuan untuk menambah bobot dari gumpalan lateks bisa menjadi bumerang kepada para petani sendiri. Justru para agen memanfaatkan caracara tersebut untuk menekan harga jual bokar dari petani. Ketika transaksi jual-beli berlangsung, para agen bisa saja melakukan pembelahan gumpalan karet. Jika didapati bahan-bahan pengotor pada gumpalan tersebut, maka agen akan membeli bokar dengan harga yang sangat murah.

Dari paparan di atas, dapat disimpulkan bahwa pemahaman dan keterampilan para petani lateks tentang proses penggumpalan lateks di kebun perlu ditingkatkan untuk meningkatkan mutu bokar yang dihasilkan. Lebih jauh, upaya ini dapat meningkatkan pendapatan petani karena meningkatnya harga jual hasil kebun mereka.Upaya ini merupakan langkah efisiensi energi dan air di pabrik pengolahan lateks yang pada gilirannya juga menurunkan biaya produksi. Juga sebagai upaya untuk menurunkan tingkat polusi bau bagi masyarakat sekitar perkebunan dan pabrik serta sebagai usaha untuk mendapatkan pembangunan yang berkelanjutan.
Untuk meningkatkan kualitas lateks gumpalan perlu melakukan substitusi koagulan yaitu dengan menggunakan asap cair. Asap cair merupakan hasil kondensasi proses pirolisis dari senyawa-senyawa yang mengandung bahan berselulosa, seperti selulusa, hemiselulosa dan lignin. Asap cair mengandung senyawa asam-asam karboksilat, karbonil, senyawa-senyawa fenol. Larutan asap cair memiliki $\mathrm{pH}$ asam sehingga kemampuan untuk mengkoagulasikan lateks cair, dan memiliki senyawa yang berfungsi untuk mencegah dan mematikan pertumbuhan bakteri yang menyebabkan protein terurai menjadi senyawa-senyawa ammonia, $\mathrm{H}_{2} \mathrm{~S}$, yang menyebabkan bau busuk.

Pengabdian kepada masyarakat ini mengambil lokasi di Dusun Alur Hitam, Desa Sekoci, Kecamatan Besitang, Kabupaten Langkat, Provinsi Sumatera Utara. Desa Sekoci ini memiliki luas daerah $36,42 \mathrm{~km}^{2}$ yang terdiri dari 8 dusun. Jumlah penduduk di Desa Sekoci adalah 4.218 jiwa dengan kepadatan sebesar $116 \mathrm{jiwa} / \mathrm{km}^{2}$. Pemilihan lokasi ini didasarkan bahwa sebagian besar penduduknya memiliki usaha perkebunan, terutama karet dan sawit. Luas tanaman perkebunan karet di Desa Sekoci adalah 2.672 ha dengan produksi 3.765 ton/ha (BPS, Besitang Dalam Angka 2015). Komoditas karet merupakan salah satu komoditas unggulan di daerah ini.

Persoalan yang dihadapi saat ini adalah rendahnya nilai jual karet petani di pasaran. Hal ini menyebabkan para petani ada yang tidak sanggup untuk memanen, disebabkan harga jual lebih rendah dari biaya memanen. Petani juga umumnya menggunakan bahan penggumpal berupa pupuk yang dapat menurunkan kualitas lateks gumpalan dimana plastisitasnya menjadi rendah serta akan menimbulkan bau yang sangat busuk.

\section{Metodologi}

Dalam upaya untuk memperkenalkan pemanfaatan asap cair sebagai bahan penggumpal lateks kepada para petani karet di Dusun Alur Hitam, maka dilakukan dua tahap kegiatan yaitu tahap persiapan dan tahap pelaksanaan di lapangan.

Pada tahap persiapan, dilakukan langkah perencanaan, perancangan, dan 
Seri Maulina. et al. Pemanfaatan Asap Cair dari Pelepah Kelapa Sawit Untuk Meningkatkan...

pembuatan reaktor pirolisis serta uji coba peralatan di laboratorium. Reaktor pirolisis hasil rancangan tim dicoba untuk membuat asap cair. Bahan baku yang digunakan adalah pelepah kelapa sawit yang diperoleh dari kawasan kampus Fakultas Teknik USU. Pelepah kelapa sawit kering dipotong-potong dan dimasak di reaktor pirolisis hingga suhu $150{ }^{\circ} \mathrm{C}$. Hasil kondensasi uap yang terbentuk kemudian ditampung sebagai produk asap cair. Nilai $\mathrm{pH}$ produk diukur menggunakan kertas indikator $\mathrm{pH}$.

Di lapangan, setelah mengadakan penyuluhan tentang upaya peningkatan kualitas bokar serta cara pembuatan asap cair, kegiatan dilanjutkan dengan demonstrasi pembuatan asap cair dari pelepah kelapa sawit dengan prosedur yang sama seperti saat uji coba peralatan di laboratorium. Setelah diperoleh produk asap cair, kemudian dilakukan demonstrasi pencampuran asap cair dan lateks cair sehingga dihasilkan gumpalan lateks.

Kemudian tim juga melakukan percobaan penggumpalan lateks dengan memvariasikan rasio asap cair terhadap lateks yaitu 1:10, 1:15, dan 1:20 (b/b). Pada saat penggumpalan, dicatat waktu yang dibutuhkan untuk penggumpalan lateks. Selanjutnya, sampel dikarakterisasi untuk mendapatkan nilai kadar air (yang setara dengan kadar karet kering), tensile strength (TS), elongation at break (EB), dan modulus of elasticity (MOE).

\section{Hasil dan Pembahasan}

Dari rangkaian kegiatan yang dilakukan pada tahap persiapan dan pelaksanaan di lapangan, maka hasil yang dicapai dapat dilihat pada Tabel 1 .

Pada saat kegiatan di lapangan, tergali beberapa informasi terkait dengan praktik penggumpalan lateks di kalangan petani selama ini. Selain menggunakan pupuk, para petani juga menggunakan air perasan mengkudu dan getah pohon pakis. Kesemua bahan tersebut memang bersifat asam dan dapat digunakan untuk menggumpalkan lateks. Namun, kesemuanya tidak mampu menghalangi terjadinya kerusakan protein yang menimbulkan bau busuk dari lateks. Selain itu, kualitas lateks yang dihasilkan cukup rendah. Dari hasil perbincangan dengan petani, para agen biasanya hanya menghargai produk mereka dengan kadar karet kering sebesar 53\%. Para agen pernah pula hanya menetapkan kadar $49 \%$. Akibatnya para petani akan menderita kerugian, dimana hasil yang diperoleh tidak mampu menutupi biaya pemanenan dan transportasi.

Tabel 1. Kegiatan dan hasil pelaksanaan Pengabdian Masyarakat

\begin{tabular}{|l|l|}
\hline \multicolumn{1}{|c|}{ Kegiatan } & \multicolumn{1}{c|}{ Hasil } \\
\hline $\begin{array}{l}\text { Merencanakan, } \\
\text { merancang, dan } \\
\text { membuat alat pirolisis }\end{array}$ & $\begin{array}{l}\text { Rangkaian peralatan } \\
\text { proses pirolisis } \\
\text { (Gambar 1) }\end{array}$ \\
\hline $\begin{array}{l}\text { Mengadakan } \\
\text { penyuluhan tentang } \\
\text { sifat-sifat dan kualitas } \\
\text { lateks cair }\end{array}$ & $\begin{array}{l}\text { Peningkatan } \\
\text { pemahaman dan } \\
\text { keterampilan mitra } \\
\text { untuk mendapatkan } \\
\text { gumpalan lateks } \\
\text { berkualitas }\end{array}$ \\
\hline $\begin{array}{l}\text { Melaksanakan proses } \\
\text { pirolisis pelepah } \\
\text { kelapa sawit }\end{array}$ & $\begin{array}{l}\text { Asap cair } \\
\text { Melaksanakan proses } \\
\text { koagulasi lateks } \\
\text { menggunakan asap } \\
\text { cair }\end{array}$ \\
& - Peningkatan \\
& kuantitas dan \\
& kualitas produksi \\
& gumpalan lateks \\
Peningkatan omzet & para petani karet \\
\hline
\end{tabular}

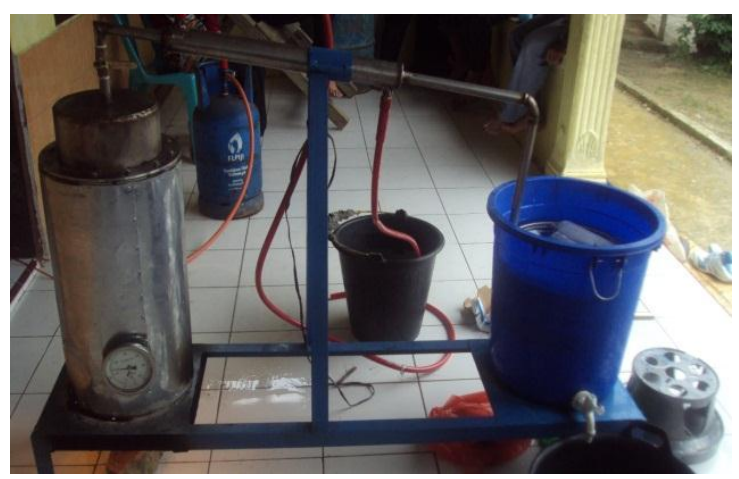

Gambar 1. Rangkaian peralatan pirolisis hasil rancangan tim yang kemudian disumbangkan kepada masyarakat

\subsection{Karakteristik Produk Asap Cair}

Asap cair yang dihasilkan berwarna coklat dengan hasil pembacaan nilai $\mathrm{pH}$ pada kertas indikator $\mathrm{pH}$ adalah 3 dan aroma asap yang menyengat. Pemasakan di rekator pirolisis membutuhkan waktu sekitar 1 jam untuk mencapai suhu $150{ }^{\circ} \mathrm{C}$.

Warna asap cair yang dihasilkan sangat tergantung kepada komposisi kimianya. 
Seri Maulina. et al. Pemanfaatan Asap Cair dari Pelepah Kelapa Sawit Untuk Meningkatkan...

Warnanya berkisar dari kuning keemasan hingga coklat gelap. Senyawa yang memberikan pengaruh utama kepada warna asap cair adalah senyawa karbonil (aldehid dan keton) juga karena interaksinya dengan gugus amino (Girard, 1992 dalam Prasetyowati dkk, 2014). Selain itu, semakin tinggi suhu dan semakin lama waktu pirolisis menyebabkan warna menjadi lebih pekat/tua.

Warna dan $\mathrm{pH}$ asap cair yang dihasilkan pada percobaan ini mirip dengan asap cair yang dihasilkan pada penelitian Rudianda Sulaeman dkk. (2013) dengan $\mathrm{pH} 3,25$. Perbandingannya dapat dilihat pada Gambar 2.
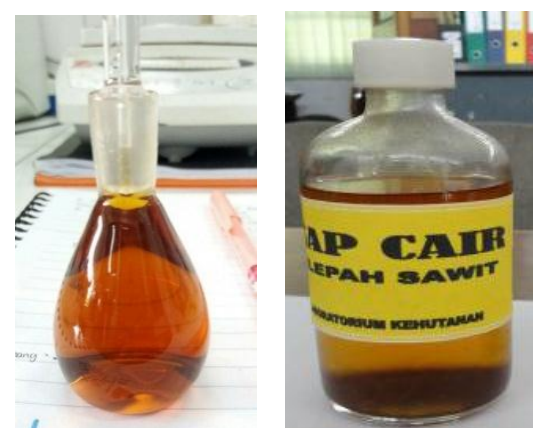

Gambar 2. Perbandingan warna asap cair dari pelepah kelapa sawit (a) percobaan ini dan (b) penelitian Rudianda Sulaeman dkk. (2013)

\subsection{Penggumpalan Lateks Menggunakan Asap Cair \\ Hasil percobaan penggumpalan lateks} pada tiga variasi rasio asap cair terhadap lateks cair yaitu 1:10, 1:15, dan 1:20 (b/b) ditampilkan pada Tabel 2.

Pada pemakaian jumlah asap cair yang sama, maka dibutuhkan waktu yang lebih lama untuk menggumpalkan lateks yang lebih banyak. Penambahan volume lateks sebesar $20 \mathrm{ml}$ menambah waktu rata-rata sebesar 1 menit.

Selanjutnya dari segi kadar air, terlihat bahwa nilainya berada dalam rentang 26,52 hingga $28,65 \%$. Hal ini menunjukkan bahwa kadar karet kering (K3) yang dapat dihasilkan dapat mencapai $73,48 \%$. Pada saat proses penggumpalan, terlihat adanya air yang terpisah dari gumpalan dan dapat dengan mudah dibuang. Dengan demikian, bokar yang dihasilkan lebih kering.
Tabel 2. Karakteristik penggumpalan lateks menggunakan asap cair

\begin{tabular}{|l|c|c|c|}
\hline \multirow{2}{*}{$\begin{array}{c}\text { Karakteristi } \\
\mathbf{k}\end{array}$} & \multicolumn{3}{|c|}{$\begin{array}{c}\text { Rasio asap cair terhadap } \\
\text { lateks cair }(\mathbf{b} / \mathbf{b})\end{array}$} \\
\cline { 2 - 4 } & $\mathbf{1 : 1 0}$ & $\mathbf{1 : 1 5}$ & $\mathbf{1 : 2 0}$ \\
\hline $\begin{array}{l}\text { Waktu } \\
\text { penggumpala } \\
\text { n }\end{array}$ & $2^{\prime}, 25^{\prime \prime}$ & $3^{\prime}, 21^{\prime \prime}$ & $4^{\prime}, 29^{\prime \prime}$ \\
\hline Kadar air (\%) & 28,65 & 26,52 & 27,94 \\
\hline TS (MPa) & 0,098 & 0,098 & 0,196 \\
\hline EB (\%) & 165,55 & 286,93 & 178,93 \\
\hline MOE (MPa) & $\begin{array}{l}5,92.10^{-} \\
4\end{array}$ & $\begin{array}{l}3,42.10^{-} \\
4\end{array}$ & $1,09.10^{-3}$ \\
\hline
\end{tabular}

Nilai K3 yang diperoleh pada percobaan ini mendekati dengan penelitian Juniaty Towaha dkk. (2013) yang memperoleh nilai K3 sebesar $75,71 \%$ pada penggunaan asap cair dari tempurung kelapa. Lebih jauh, jika dibandingkan dengan nilai K3 bokar petani karet di Dusun Alur Hitam, maka nilai ini tentu saja lebih tinggi. Penggunaan asap cair dari pelepah kelapa sawit dapat meningkatkan nilai K3 hingga 20,48\%. Peningkatan nilai ini diharapkan dapat meningkatkan harga jual karet sehingga meningkatkan pendapatan petani. Hanya saja, para petani menyampaikan bahwa mereka tidak dapat langsung menjual ke pabrik, namun harus melalui agen. Para agen umumnya lebih memilih harga jual yang rendah dari petani. Untuk itu disarankan agar para petani bersatu membentuk kelompok tani atau koperasi.

Nilai tensile strength (TS) dan modulus of elasticity (MOE) yang diperoleh pada percobaan ini tergolong rendah; sementara nilai elongation at break (EB) atau pemanjangan saat putus sudah cukup baik. TS adalah besarnya tenaga yang dibutuhkan untuk memutuskan sebuah karet percobaan dengan cara ditarik pada kecepatan yang tetap, dimana umumnya berkisar 3-10 MPa. Sedangkan EB adalah persentase pajangnya karet pada saat karet percobaan ditarik sampai putus (panjangnya karet pada saat TS diukur) yang umumnya berkisar 60\% $1.000 \%$ (Basis Pancakarya, 2015). Pada pengolahan lebih lanjut dapat dilakukan penambahan filler ataupun plasticizer untuk meningkatkan nilai tensile strength sesuai dengan produk yang diinginkan. 
Seri Maulina. et al. Pemanfaatan Asap Cair dari Pelepah Kelapa Sawit Untuk Meningkatkan...

\section{Kesimpulan}

Dari hasil pengabdian dan percobaan yang telah dilakukan, dapat diambil kesimpulan sebagai berikut:

1. Pengetahuan dan keterampilan para petani karet perlu ditingkatkan agar kualitas karet rakyat dapat meningkat pula.

2. Para petani umumnya menggunakan pupuk disamping juga menggunakan air perasan mengkudu dan getah pohon pakis untuk menggumpalkan bokar.

3. Nilai jual bokar di kalangan petani sangat rendah dengan patokan kadar karet kering (K3) sebesar 53\% oleh para agen.

4. Asap cair yang dihasilkan mempunyai warna coklat dengan nilai $\mathrm{pH} 3$ dan aroma asap yang menyengat.

5. Asap cair dari pelepah kelapa sawit dapat digunakan sebagai penggumpal lateks dengan dengan nilai K3 terbaik yaitu $73,48 \%$. Nilai K3 meningkat sebesar $20,48 \%$ berbanding produk bokar petani selama ini.

6. Perlu didorong pembentukan kelompok tani atau koperasi di kalangan petani karet Dusun Alur Hitam.

\section{Ucapan Terima Kasih}

Kegiatan pengabdian ini terlaksana dengan dukungan dana Biaya Operasional Perguruan Tinggi Negeri (BOPTN) USU (Dana Non-PNBP) Skim Mono Tahun. Pelaksanaan pengabdian ini juga didukung oleh para mahasiswa Departemen Teknik Kimia yaitu Fikri Naufal Anwari, Muhammad Iriansyah, Fadhil Al-Farouq Sinaga, Frist Silia, dan Feni Sari Putri.

\section{Daftar Pustaka}

BPS. Besitang Dalam Angka 2015. https://langkatkab.bps.go.id/website/p df_publikasi/ Besitang-Dalam-Angka2015.pdf. Diakses tanggal 1 Juli 2016.

Basis Pancakarya. 2015. Spesifikasi Karet. http://www.basisrubber.com/id/spesi fikasi-karet.html. Diakses tanggal 5 Desember 2016.

GAPKINDO. 2014. Rubber production in Indonesia 20092013 (in thousand tons). http://www.gapkindo.org/en/componen t/content/article/1-artikel/152perkebunan-lateks-alam-eng. Diakses tanggal 26 April 2015.

GAPKINDO. 2014. Area of rubber plantation of Indonesia 2008-2013 (in thousand hectares).

http://www.gapkindo.org/en/ component/content/article/1artikel/148-luas-perkebunan-latekseng. Diakses 26 April 2015.

Juniaty Towaha, Asif Aunillah, Eko Heri Purwanto. 2013. Pemanfaatan Asap Cair Kayu Karet dan Tempurung Kelapa untuk Penanganan Polusi Udara pada Lump. Buletin RISTRI, 4(1): 71-80.

Maulina, Seri. 2015. Enhancement of EcoEfficiency through life cycle assessment in crumb rubber processing. Elsevier Procedia-Social and Behaviour Sciences. Vol 195: 2475-2484.

Prasetyowati, Ayu Putri Novianty, Mutia Risa Haryuni. 2014. Pembuatan Asap Cair dari Limbah Kulit Singkong (Manihot Esculenta $L$. Skin) untuk Bahan Pengawet Kayu. Jurnal Teknik Kimia, No. 1, Vol. 20: 64-75.

Rudianda Sulaeman, Rusli Rustam, Gulat ME Manurung. 2013. Pemanfaatan Tandan Kosong Sawit Sebagai Bahan Baku Asap Cair (Liquid Smoke). Prosiding Seminar Nasional "Peranan Teknologi dan Kelembagaan Pertanian dalam Mewujudkan Pembangunan Pertanian yang Tangguh dan Berkelanjutan". November 2013. Pekanbaru, Indonesia. Hal. 388-394. 